\title{
Long-term variability in reconstructed and observed snow cover over the last 100 winter seasons in Cracow and Zakopane (southern Poland)
}

\author{
Małgorzata Falarz* \\ Institute of Meteorology and Water Management, 30-215 Cracow, Borowego 14, Poland
}

\begin{abstract}
An attempt to reconstruct the seasonal snow cover data in Cracow (for 26 winter seasons) and Zakopane (for 19 winter seasons) at the turn of the 20th century based on climatic data was made by using multiple regression. The results of the reconstruction were more successful for the station located at lower altitude (Cracow, $206 \mathrm{~m}$ above sea level) and allowed an analysis of nival conditions to be extended over 104 winter seasons. The reconstructed data obtained for Zakopane (857 $\mathrm{m}$ above sea level) appear to be overestimated for the number of snow cover days and sum of daily snow cover depth. Thus, they were excluded from further calculations. The mean snow cover duration at Zakopane $\left(128 \mathrm{~d} \mathrm{yr}^{-1}\right)$ is twice as long as that at Cracow. An analysis of long-term variability of seasonal snow cover duration, seasonal maximum snow depth and sum of daily snow cover depth in Cracow for the period 1895/96-1998/99 and in Zakopane for the periods 1895/96-1998/99 and 1914/15-1998/99 showed no statistically significant trend in any case. The statistically significant $(\mathrm{p}<0.05)$ decreasing trend of snow cover duration at both stations $(-13 \mathrm{~d} / 10 \mathrm{yr}$ in Cracow, $-8 \mathrm{~d} / 10 \mathrm{yr}$ in Zakopane) in the period 1961-1990 could be selected for the whole period investigated. The variation coefficient for snow cover duration is over twice as large for Cracow (37\%) as for Zakopane $(15 \%)$.
\end{abstract}

KEY WORDS: Snow cover - Reconstruction - Climate variability - Time series analysis · Southern Poland

Resale or republication not permitted without written consent of the publisher

\section{INTRODUCTION}

Quite regular, documented snow cover observations in southern Poland appeared in meteorological reports only in the 1920s or 1930s. Therefore it is practically impossible to track the changes in snow cover over a period longer than 70 to $80 \mathrm{yr}$ and to compare them with changes of thermal and precipitation conditions observed in the last century. An analysis of long-term variability of snow cover can provide detailed information on climate changes in winter seasons. The state of snow cover resulting from the interaction of thermal and precipitation conditions and indirectly from atmo-

*E-mail: malgosiafa@poczta.onet.pl spheric circulation can be used as a good indicator of climatic conditions.

The availability of data related to climate elements that influence snow cover formation, persistence and disappearance allows the reconstruction of nival conditions for the periods when no snow cover observations were made or for which relevant records are missing, unreliable or unavailable.

This study is focused on the following objectives: (1) methodical - an attempt to reconstruct nival data at the turn of the 20th century based on available information on circulation, thermal and precipitation conditions; (2) cognitive-an investigation of long-term variability of snow cover in southern Poland based on both observed and reconstructed nival data. 
Reconstruction of Canadian snow cover was carried out by Brown \& Goodison (1996) based on a model including daily total solid precipitation, maximum daily temperature, quantity of water from melted snow and depth of snow cover for the previous day. The best results were obtained for southern Canada, where the reconstruction method was able to account for 70 to $80 \%$ of the variance in annual snow cover duration, with mean annual bias values of $<5 \mathrm{~d}$. Twardosz (1999) reconstructed monthly and annual precipitation totals in Cracow for the period 1812-1849 using a simple regression method based on the number of days with precipitation. The observed nival data series for southern Poland taken from the last 50 to 76 winter seasons were analysed by Falarz (1998) and Falarz et al. (1998). A slight, but not statistically significant, decreasing trend of snow cover characteristics was observed at the majority of stations in southern Poland. The downward tendency is more evident from the beginning of the 1960s. In the neighbouring region of Slovakia, a decreasing trend in the number of days with snow cover in the lowlands and low basins and an increasing trend in the Carpathians were observed in the period 1920/21-1984/85 (Šamaj et al. 1991).

Other research of long-term snow cover variability in the whole Northern Hemisphere and in its various areas concerning mainly the snow cover duration indicates a decrease (most results, e.g. Estonia: Jaagus 1997; North America: Karl et al. 1993; Northern Hemisphere: Gutzler \& Rosen 1992, Groisman et al. 1994), an increase (e.g. northern Russia: Ye et al. 1998; Great Plains, USA: Hughes \& Robinson 1996) or no tendency (e.g. Canada: Brown \& Goodison 1996; Switzerland: Beniston et al. 1994).

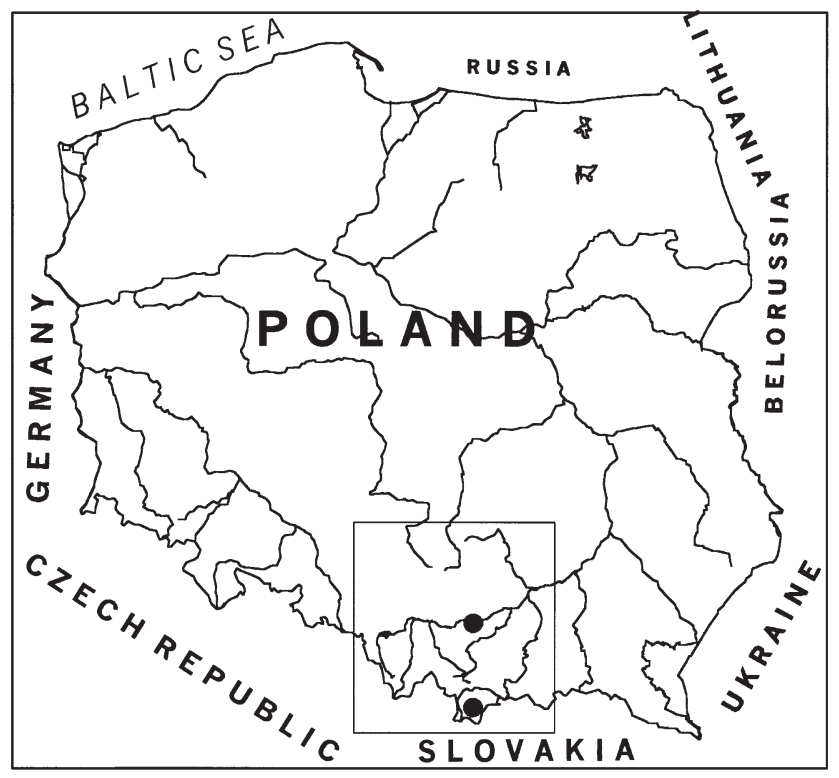

\section{DATA AND METHOD}

The nival, temperature and precipitation data from the following 2 first-order climatological Polish stations were analysed: Cracow, a city located in the upper Vistula valley in the Carpathian Foothills, $206 \mathrm{~m}$ above sea level, and Zakopane, a town situated at the foot of the Tatra mountains, $857 \mathrm{~m}$ above sea level (Fig. 1). In addition, the atmospheric circulation indices (westerly zonal, southerly meridional and cyclonicity index) obtained by Niedźwiedź (1993, 1998, 2000) for the Central Europe and the North Atlantic Oscillation (NAO) index (CRU 2000) were used.

Direct data related to snow cover in Cracow in the period 1921/22-1998/99 (78 winter seasons) and in Zakopane in the period 1914/15-1998/99 (85 winter seasons) were collected. Data series for both stations are of a high quality: fully continuous for the whole examined period including the time of the Second World War for Cracow (Jagiellonian University station located in the centre of the city) and with gaps for a total of 6 mo only in the period 1919-1922 for Zakopane. Due to a lack of any other snow data series of such length significantly correlated with Zakopane, the missing data were completed by using mean values for the whole period. For the same reason, the homogeneity of the snow cover series for the investigated period could be checked only by using an absolute test (standard normal homogeneity testsingle series; Stepanek 2000). The relative Alexandersson test (Alexandersson 1986) was used only for the 50 winter seasons of 1949/50-1998/99 based on the regional data series. No statistically significant inhomogeneity in the number of days with snow cover, maximum depth of snow cover or sum of daily snow cover depth was detected in the seasonal snow cover series of 2 stations.

Both stations are situated in southern Poland quite a short distance from each other (about $100 \mathrm{~km}$ ); however, due to a specific localisation and different elevations, they have different annual snow cover patterns (Fig. 2). In Cracow (lowland station) the average

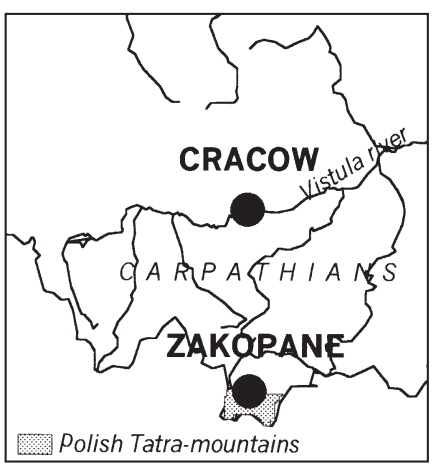

Fig. 1. Location of stations analysed in this study 

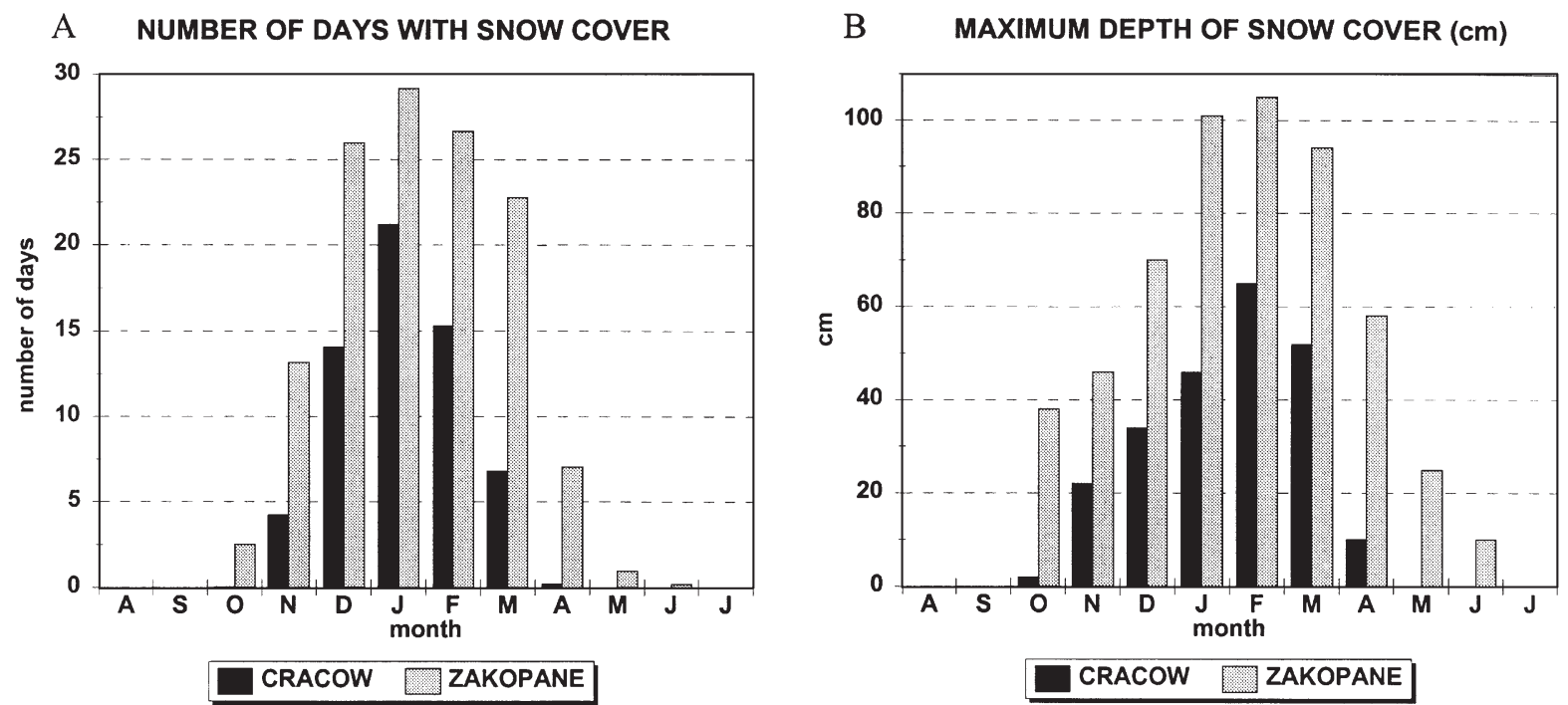

Fig. 2. Annual patterns of (A) the average number of days with snow cover and (B) the maximum depth of snow cover in Cracow and Zakopane for the normal period 1961-1990

annual number of days with snow cover $\geq 1 \mathrm{~cm}$ for the 'normal' period 1961-1990 is 62 (with $21 \mathrm{~d}$ in January) and there is less than half that number for Zakopane (low mountain station; $128 \mathrm{~d}$ of snow cover a year; $29 \mathrm{~d}$ in January). The absolute maximum snow cover depth was observed in February: $65 \mathrm{~cm}$ in Cracow (1963) and $105 \mathrm{~cm}$ (1962) in Zakopane (1961-1990). The potential period of snow cover occurrence is on average $114 \mathrm{~d}$ in Cracow (24 November to 13 March) and exceeds 6 mo in Zakopane (188 di 28 October to 3 May). Multiannual data series of both stations are not significantly correlated, neither for snow cover duration nor for maximum snow cover depth. There are usually many thaws during the winter season in Cracow, so snow cover appears and disappears a few times a winter. The snow cover in Zakopane is more consistent.

The reconstruction of nival conditions was made for 3 snow cover characteristics (number of days with snow cover, maximum depth of snow cover and sum of daily snow cover depth) using multiple regression. An attempt at reconstruction for the years 1895/961920/21 (26 winter seasons) in Cracow was carried out to extend an analysis of nival conditions to 104 winter seasons. A successful reconstruction for the years 1895/96-1913/14 (19 winter seasons) in Zakopane would result in a data series of the same length as that for Cracow. Reconstruction was carried out as follows:

(1) The climatic parameters that were strongly related to nival conditions and were available for the period before snow cover observations were chosen. The statistically significant correlation coefficients of 3 snow cover characteristics and other selected climatic elements and indices are shown in Table 1a. The number of days with snow precipitation appeared to be far better correlated with nival conditions than that of both snow and mixed precipitation. At the same time the dependence of snow cover on the NAO index (CRU 2000) is weaker than that of the zonal westerly circulation index based on mesoscale Central European circulation (Niedźwiedź 1988, 1992, 1993, 1998, pers. comm). The correlation between snow cover and cyclonicity index is insignificant in all cases. The climatic characteristics chosen initially for the reconstruction of seasonal nival conditions are shown in Table 1b. It has been found that the strongest correlation coefficients with seasonal snow cover characteristics contain all climatic elements and indices considered for the period December-February in Cracow and some of them for a longer part of the year (October-April or October-February) or for the whole snow cover year (August-July) in Zakopane.

(2) The multiple regression equations were calculated for the basic period 1966/67-1995/96 (30 winter seasons) while taking into account the snow cover dependence on characteristics quoted in Table $1 \mathrm{~b}$. Among many combinations, the equations with the highest confidence level for their components, the lowest standard error of the estimate, and a coefficient of determination as high as possible have been chosen. Thus not every characteristic selected initially was included in the final models. The models that produced improbable (e.g. negative) nival characteristics were also rejected. The final equations and their characteristics are presented in Table 2 .

(3) The results obtained from the snow cover reconstruction by using the regression equations were 
Table 1. (a) Correlation coefficients of snow cover characteristics and the other climatic elements (basic period: 1966/67-1995/96). Only the coefficients significant at $\mathrm{p}<0.05$ are shown. Period: the period of the highest correlation of climatic elements with the seasonal snow cover characteristic. (b) Climatic characteristics chosen initially for the reconstruction of seasonal snow conditions

\begin{tabular}{|c|c|c|c|c|c|c|c|}
\hline $\begin{array}{l}\text { Snow cover characteristic } \\
\text { (whole season) } \\
\text { Stn }\end{array}$ & $\begin{array}{l}\text { Mean air } \\
\text { tempera- } \\
\text { ture }\end{array}$ & $\begin{array}{l}\text { (a) Correlati } \\
\text { Number of } \\
\text { days with } \\
\text { snow } \\
\text { precipitation }\end{array}$ & $\begin{array}{l}\text { on coefficients } \\
\text { Number of } \\
\text { days with } \\
\text { snow and mixed } \\
\text { precipitation }\end{array}$ & $\begin{array}{l}\text { Zonal } \\
\text { westerly } \\
\text { circulation } \\
\text { index }\end{array}$ & $\begin{array}{l}\text { Southerly } \\
\text { meridional } \\
\text { circulation } \\
\text { index }\end{array}$ & $\begin{array}{l}\text { Cycloni- } \\
\text { city } \\
\text { index }\end{array}$ & $\begin{array}{l}\text { NAO } \\
\text { index }\end{array}$ \\
\hline \multicolumn{8}{|l|}{ Cracow } \\
\hline $\begin{array}{l}\text { Number of days with snow cover } \\
\text { Period }\end{array}$ & $\begin{array}{c}-0.85 \\
\text { Dec-Feb }\end{array}$ & $\begin{array}{c}0.84 \\
\text { Dec-Feb }\end{array}$ & $\begin{array}{c}0.75 \\
\text { Dec-Feb }\end{array}$ & $\begin{array}{c}-0.82 \\
\text { Dec-Feb }\end{array}$ & - & - & $\begin{array}{c}-0.76 \\
\text { Dec-Feb }\end{array}$ \\
\hline $\begin{array}{l}\text { Maximum depth of snow cover } \\
\text { Period }\end{array}$ & $\begin{array}{c}-0.72 \\
\text { Dec-Feb }\end{array}$ & $\begin{array}{c}0.74 \\
\text { Dec-Feb }\end{array}$ & $\begin{array}{c}0.69 \\
\text { Dec-Feb }\end{array}$ & $\begin{array}{c}-0.69 \\
\text { Dec-Feb }\end{array}$ & - & - & $\begin{array}{c}-0.46 \\
\text { Dec-Feb }\end{array}$ \\
\hline $\begin{array}{l}\text { Sum of daily snow cover depth } \\
\text { Period }\end{array}$ & $\begin{array}{c}-0.74 \\
\text { Dec-Feb }\end{array}$ & $\begin{array}{c}0.82 \\
\text { Dec-Feb }\end{array}$ & $\begin{array}{c}0.75 \\
\text { Dec-Feb }\end{array}$ & $\begin{array}{c}-0.77 \\
\text { Dec-Feb }\end{array}$ & - & - & $\begin{array}{c}-0.57 \\
\text { Dec-Feb }\end{array}$ \\
\hline \multicolumn{8}{|l|}{ Zakopane } \\
\hline $\begin{array}{l}\text { Number of days with snow cover } \\
\text { Period }\end{array}$ & $\begin{array}{l}-0.53 \\
\text { Oct-Apr }\end{array}$ & $\begin{array}{c}0.68 \\
\text { Oct-Apr }\end{array}$ & $\begin{array}{c}0.54 \\
\text { Oct-Apr }\end{array}$ & $\begin{array}{c}-0.37 \\
\text { Aug-Jul }\end{array}$ & - & - & - \\
\hline $\begin{array}{l}\text { Maximum depth of snow cover } \\
\text { Period }\end{array}$ & $\begin{array}{c}-0.47 \\
\text { Dec-Feb }\end{array}$ & $\begin{array}{c}0.52 \\
\text { Oct-Apr }\end{array}$ & $\begin{array}{c}0.52 \\
\text { Dec-Feb }\end{array}$ & - & - & - & - \\
\hline $\begin{array}{l}\text { Sum of daily snow cover depth } \\
\text { Period }\end{array}$ & $\begin{array}{c}-0.52 \\
\text { Dec-Feb }\end{array}$ & $\begin{array}{c}0.70 \\
\text { Oct-Feb }\end{array}$ & $\begin{array}{c}0.55 \\
\text { Dec-Feb }\end{array}$ & - & $\begin{array}{c}-0.46 \\
\text { Dec-Feb }\end{array}$ & - & - \\
\hline \multicolumn{8}{|c|}{ (b) Climatic characteristics } \\
\hline \multicolumn{2}{|c|}{$\begin{array}{l}\text { Cracow } \\
\text { - Mean air temperature (Dec-Feb) } \\
\text { - Number of snowfall days (Dec-Feb) } \\
\text { - Zonal westerly circulation index (Dec-Feb) }\end{array}$} & \multicolumn{2}{|l|}{ As on the left } & \multicolumn{4}{|c|}{ As on the left } \\
\hline \multicolumn{2}{|c|}{$\begin{array}{l}\text { Zakopane } \\
\text { - Mean air temperature (Oct-Apr) } \\
\text { - Number of snowfall days (Oct-Apr) } \\
\text { - Zonal westerly circulation index (Aug-Jul) }\end{array}$} & \multicolumn{6}{|c|}{$\begin{array}{l}\text { - Mean air temperature (Dec-Feb) } \\
\text { - Number of snowfall days (Oct-Feb) } \\
\text { - Southerly circulation index (Dec-Feb) }\end{array}$} \\
\hline
\end{tabular}

verified and compared with observational data gathered for the basic (1966/67-1995/96) and reference (1941/42-1965/66) periods (Table 3, Figs 3 \& 4).

(4) The snow cover characteristics were determined for the period when no nival records were gathered.

The second objective was reached by investigating and comparing the long-term snow cover characteristics for both stations and by analysing the obtained time series. The variation coefficient was defined as the percentage ratio of the standard deviation to the arithmetic mean of the nival characteristic. The average change (described by the linear trend) of snow cover characteristics per 100 (10) yr was counted. A relative measure of long-term snow cover change comparable for both station and all nival characteristics is a change index defined as the percentage ratio of the average change in snow cover per 100 (10) yr to the arithmetic mean of the nival characteristic.

Table 2. Final equations for the snow cover reconstruction. ND SC: number of days with snow cover; MAX TH: maximum depth of snow cover; SUM SC: sum of daily snow cover depth; TAVG: mean temperature; PSN: number of days with snow precipitation;

WNDX: westerly zonal circulation index; SNDX: southerly meridional circulation index. SE: standard error of the estimate

\begin{tabular}{|c|c|c|c|c|}
\hline Stn & Linear equation & $\mathrm{R}$ & $\mathrm{R}^{2}$ & SE \\
\hline \multirow[t]{3}{*}{ Cracow } & $\mathrm{ND} \mathrm{SC}=1.398 \mathrm{PSN}_{(\mathrm{Dec}-\mathrm{Feb})}-0.396 \mathrm{WNDX}_{(\mathrm{Dec}-\mathrm{Feb})}+43.9$ & 0.92 & 0.85 & $\pm 11 \mathrm{~d}$ \\
\hline & MAX TH $=0.470 \mathrm{PSN}_{(\mathrm{Dec}-\mathrm{Feb})}-0.113 \mathrm{WNDX}_{(\mathrm{Dec}-\mathrm{Feb})}+15.2$ & 0.80 & 0.64 & $\pm 6 \mathrm{~cm}$ \\
\hline & SUM SC $=-69.119$ TAVG $_{(\text {Dec-Feb })}+34.998 \mathrm{PSN}_{(\mathrm{Dec}-\mathrm{Feb})}-232.9$ & 0.83 & 0.69 & $\pm 336 \mathrm{~cm}$ \\
\hline \multirow[t]{3}{*}{ Zakopane } & $\mathrm{ND} \mathrm{SC}=0.997 \mathrm{PSN}_{(\mathrm{Oct}-\mathrm{Apr})}-0.126 \mathrm{WNDX}_{(\text {Aug-Jul })}+95.4$ & 0.78 & 0.60 & $\pm 11 \mathrm{~d}$ \\
\hline & $\mathrm{MAX} \mathrm{TH}=-3.006 \mathrm{TAVG}_{(\mathrm{Dec}-\mathrm{Feb})}+0.622 \mathrm{PSN}_{(\mathrm{Oct}-\mathrm{Apr})}+22.2$ & 0.58 & 0.33 & $\pm 16 \mathrm{~cm}$ \\
\hline & $\mathrm{SUM}$ SC $=-247.376 \mathrm{TAVG}_{(\mathrm{Dec}-\mathrm{Feb})}+88.814 \mathrm{PSN}_{(\mathrm{Oct}-\mathrm{Feb})}-17.104 \mathrm{SNDX}_{(\mathrm{Dec}-\mathrm{Feb})}-509.3$ & 0.76 & 0.58 & $\pm 1042 \mathrm{~cm}$ \\
\hline
\end{tabular}


Table 3. Comparison of the observed and reconstructed snow cover data in the basic (1966/67-1995/96) and reference (1941/42-1965/66) periods. Obs.: observed data; Rec.: reconstructed data

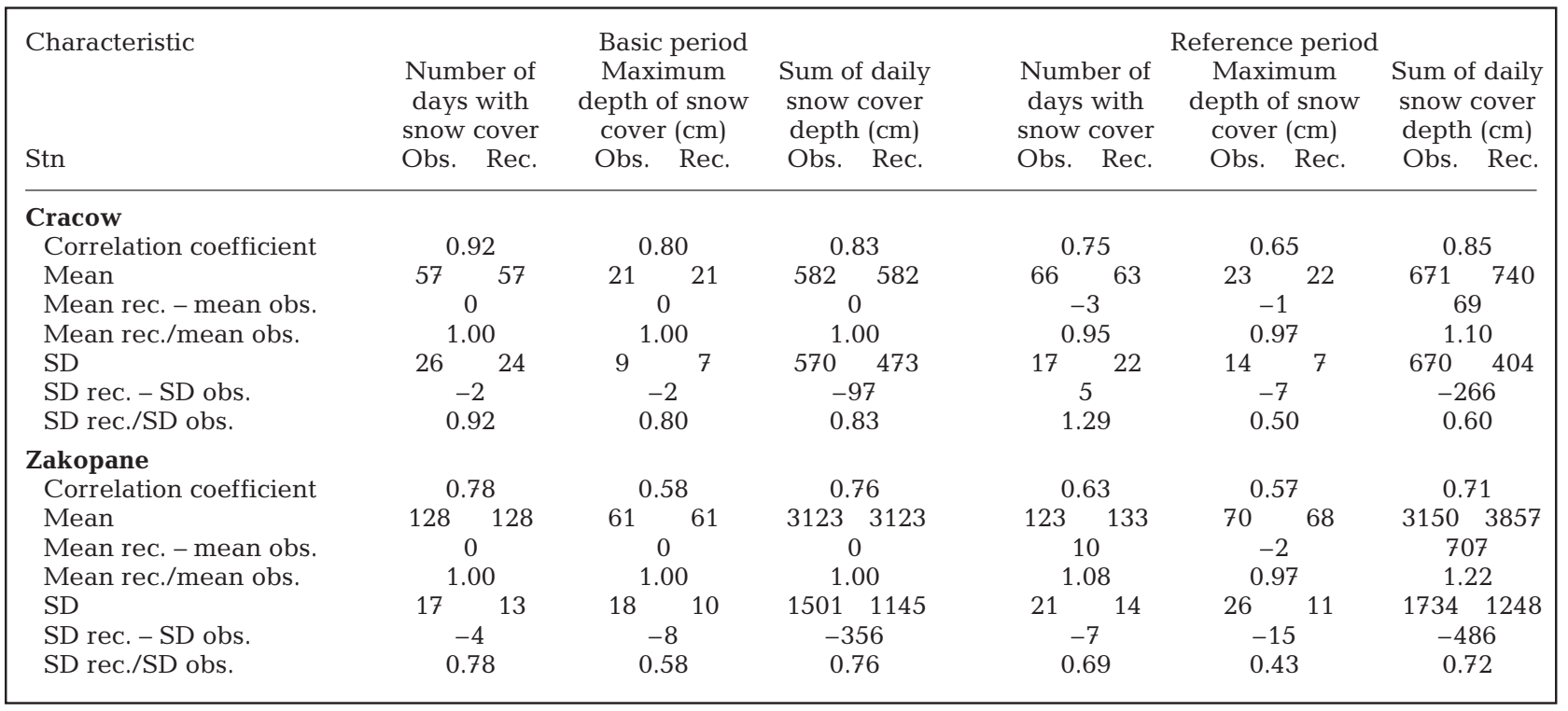

\section{RESULTS}

Except for the sum of snow cover depth for Zakopane, all the final regression equations used for nival data reconstruction contain 2 components, one of which is the number of days with snow precipitation (Table 2). The equations obtained for Cracow $\left(\mathrm{R}^{2}=\right.$ 0.64 to 0.85 ) described the snow cover variations much better than those of Zakopane $\left(\mathrm{R}^{2}=0.33\right.$ to 0.60$)$. For each station the best reconstruction results were obtained for the number of days with snow cover, while the worst was for seasonal maximum snow cover depth. This allows a preliminary quality assessment for the reconstruction results. The standard errors of the estimate (i.e. the square roots of the mean square errors) of final equations are in most cases higher for Zakopane, but their relations to mean snow cover characteristics values point to a better data fit for Zakopane (e.g. the relative standard error for the number of days with snow cover is $19.3 \%$ for Cracow and $8.6 \%$ for Zakopane).

The comparison of the observed snow cover characteristics with those calculated from the equations used for reconstruction indicates satisfactory results for the basic period for both stations (Table 3, Figs 3 to 6). The smallest differences, as expected, are obtained for the number of snow cover days for which the fit for the $10 \mathrm{yr}$ consecutive mean is very good $(\mathrm{R}=0.92$ for Cracow, Fig. 5). Generally, the calculated values of snow cover depth maximum and sum of snow cover depth are smaller than those observed in the case of extremely high values, while for extremely low observed values they are higher (Figs 3 \& 4). Mean observed and reconstructed values for the entire basic period equal each other, while the standard deviations of observed and reconstructed values are the most consistent for the snow cover duration in Cracow.

Similar comparisons made for the reference period led to much worse results (Table 3 ). While there are no major objections to the results obtained for Cracow, the calculated number of snow cover days and sum of snow cover depth for Zakopane is clearly too high. This is mainly the result of overestimating nival characteristics in seasons with poor snow cover, which is quite obvious in Fig. 4. On the other hand the maximum depth of snow cover for this station does not reach its absolute minimum and absolute maximum values, thus resulting in a considerable flattening of the consecutive mean line and a very low standard deviation $(11 \mathrm{~cm}$, i.e. $43 \%$ of standard deviation for observed values; Fig. 6). The underestimation of higher values is in that case even bigger than for the basic period. All correlation coefficients of observed and reconstructed data are statistically significant at $\mathrm{p}<0.05$. The highest correlation was calculated for the sum of daily snow cover depth $(\mathrm{R}=$ 0.85 for Cracow and 0.71 for Zakopane). The ratio of mean reconstructed and observed data for the entire reference period does not exceed $10 \%$, except for the sum of daily snow cover depth in Zakopane. The difference between the mean reconstructed and observed values, which is zero in all cases in the basic period, reaches $-3(+10) \mathrm{d}$ with snow cover and $-1(-2) \mathrm{cm}$ of maximum snow cover depth in Cracow (Zakopane) for the entire reference period (Table 3 ). 

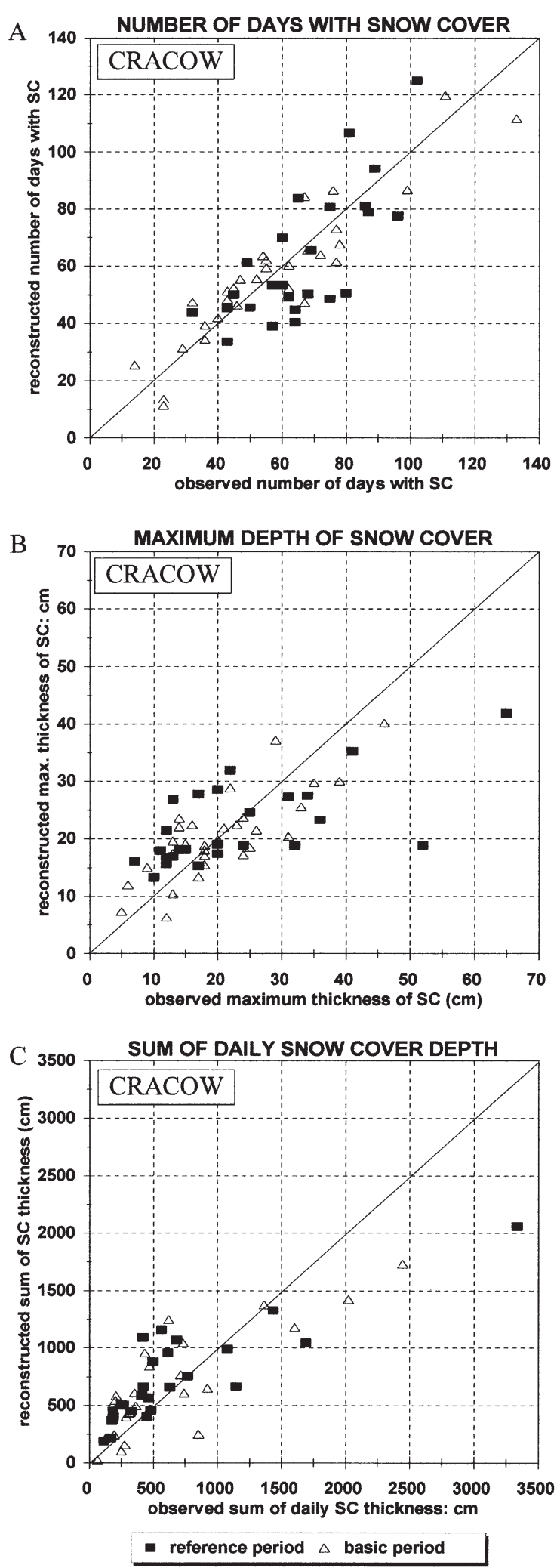

Fig. 3. Cracow: relationship between observed and reconstructed snow cover in the basic (1966/67-1995/96) and reference (1941/42-1965/66) periods. SC: snow cover. Line of $\mathrm{r}=$ 1 added
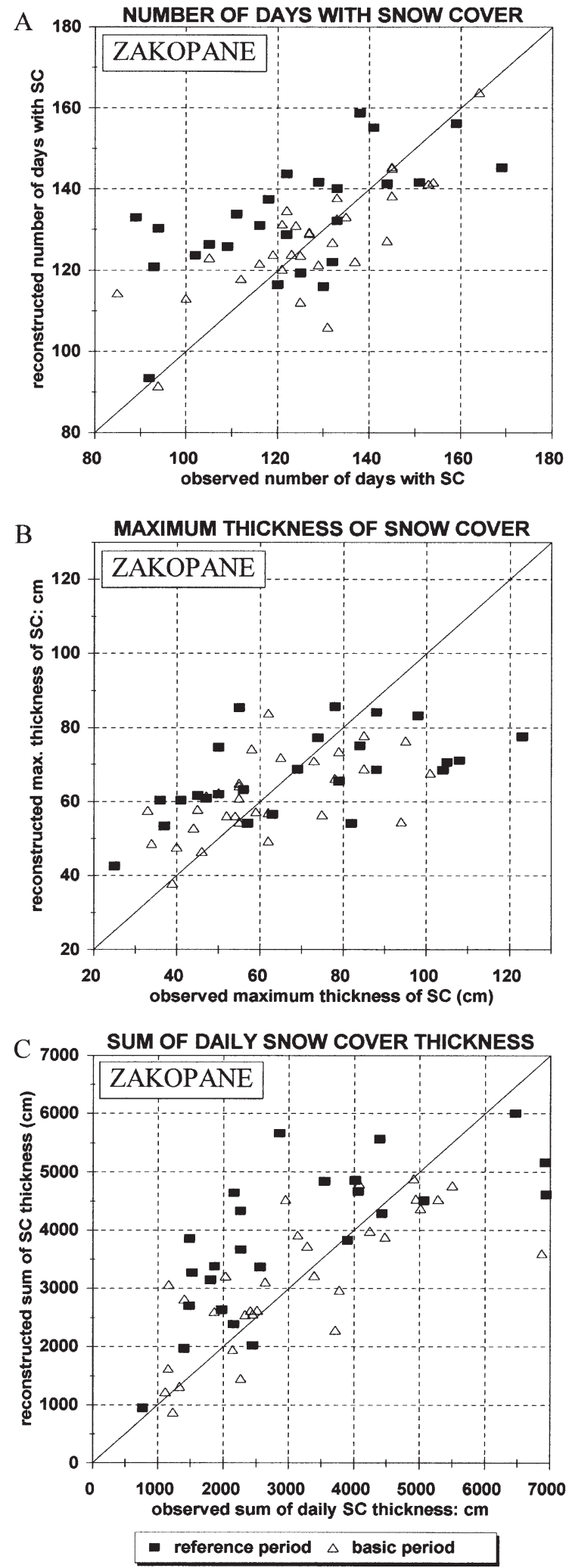

Fig. 4. Zakopane: relationship between observed and reconstructed snow cover in the basic (1966/67-1995/96) and reference (1941/42-1965/66) periods. SC: snow cover. Line of $\mathrm{r}=1$ added 
The considerably overestimated sum of daily snow cover depth (by $22 \%$ on average) in Zakopane within the reference period causes the results of the reconstruction for the turn of the 20th century to become less reliable and could be called into question. The second case with uncertain results of reconstruction seems to be the number of days with snow cover in Zakopane. The relative error is rather small within the reference period $(8 \%)$. However the absolute values of the overestimation are quite large (an average of $10 \mathrm{~d}$ per winter season), and moreover the overestimation here is constant for almost the whole reference period. It is quite noticeable in the run of the $10 \mathrm{yr}$ moving average line (Fig. 6A). The situation here is very similar to the one for sum of snow depth and seems to indicate similar overestimation for the reconstructed values before the observation period (Fig. 6C). Thus, these 2 cases were excluded from statistical analysis performed for multi-year time series. It was assumed that it is better to examine a shorter period than to draw bad conclusions. It is still difficult to explain such discrepancies. An analysis of equation components has shown no data errors for the reference period. Also, many attempts to use other equations and to eliminate individual components have failed.

The principal statistical parameters for snow cover time series containing (1) both observed and reconstructed values for all 3 snow cover characteristics in Cracow and for the maximum snow cover depth in Zakopane (104 winter seasons) and (2) observed values only for the number of days with snow cover and sum of snow cover depth in Zakopane (85 winter seasons) are presented in Table 4. No statistically significant tendency in snow cover variability was found in any of the 6 cases. The average change (linear trend) is $+3.5 \mathrm{~d}$ of snow cover duration and $+2 \mathrm{~cm}$ of snow cover maximum depth per $100 \mathrm{yr}$ in Cracow. The relative change is the highest for the maximum of snow cover depth: positive in Cracow (10\%/100 yr), and negative but similar in its absolute value in Zakopane $(-11 \% / 100 \mathrm{yr})$. The statisti-
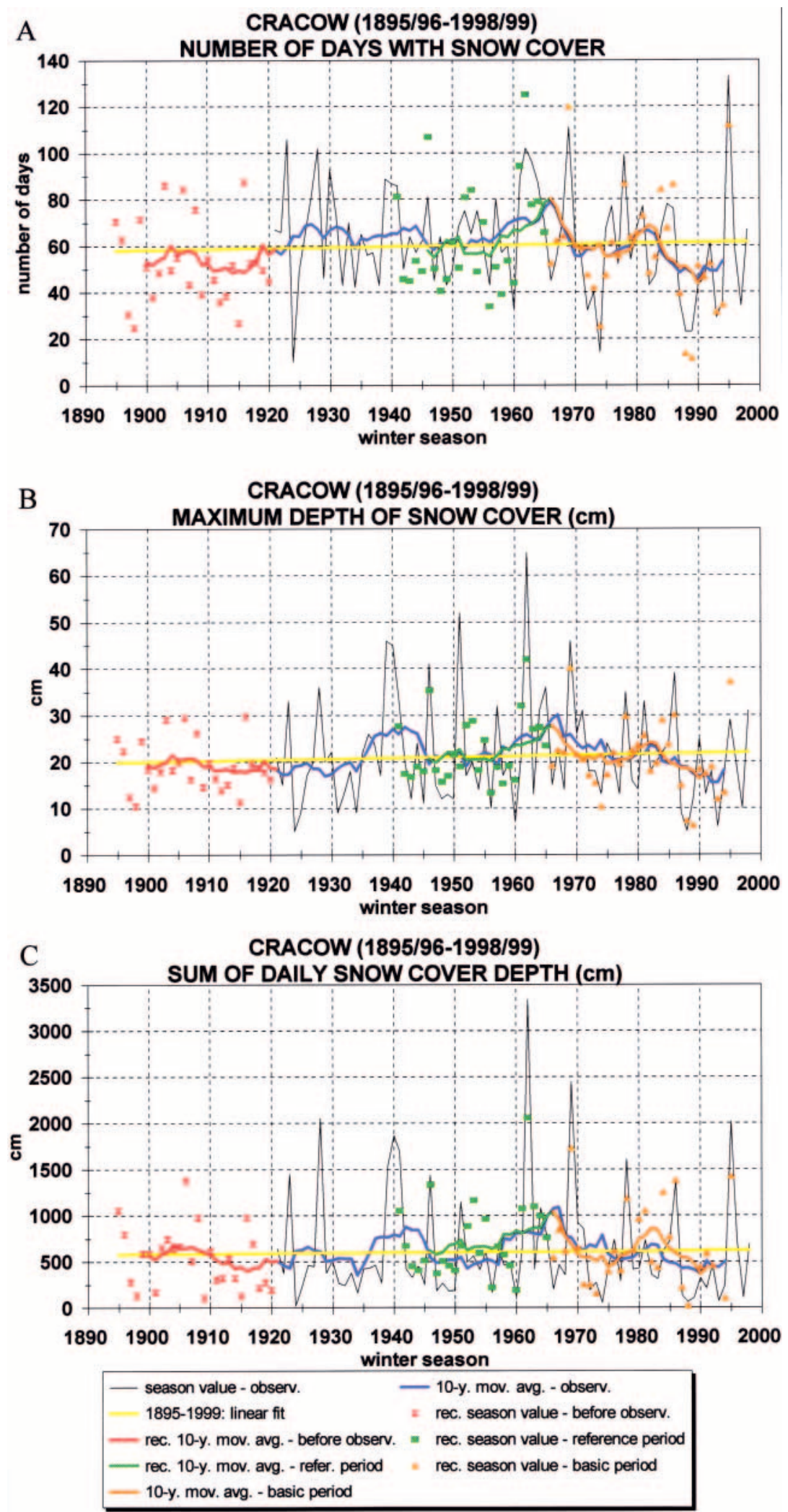

Fig. 5. Cracow: observed and reconstructed snow cover characteristics (1895/96-1998/99); observ.: observed; rec.: reconstructed; refer.: reference; 1900 means the winter season of 1900/01 etc. 

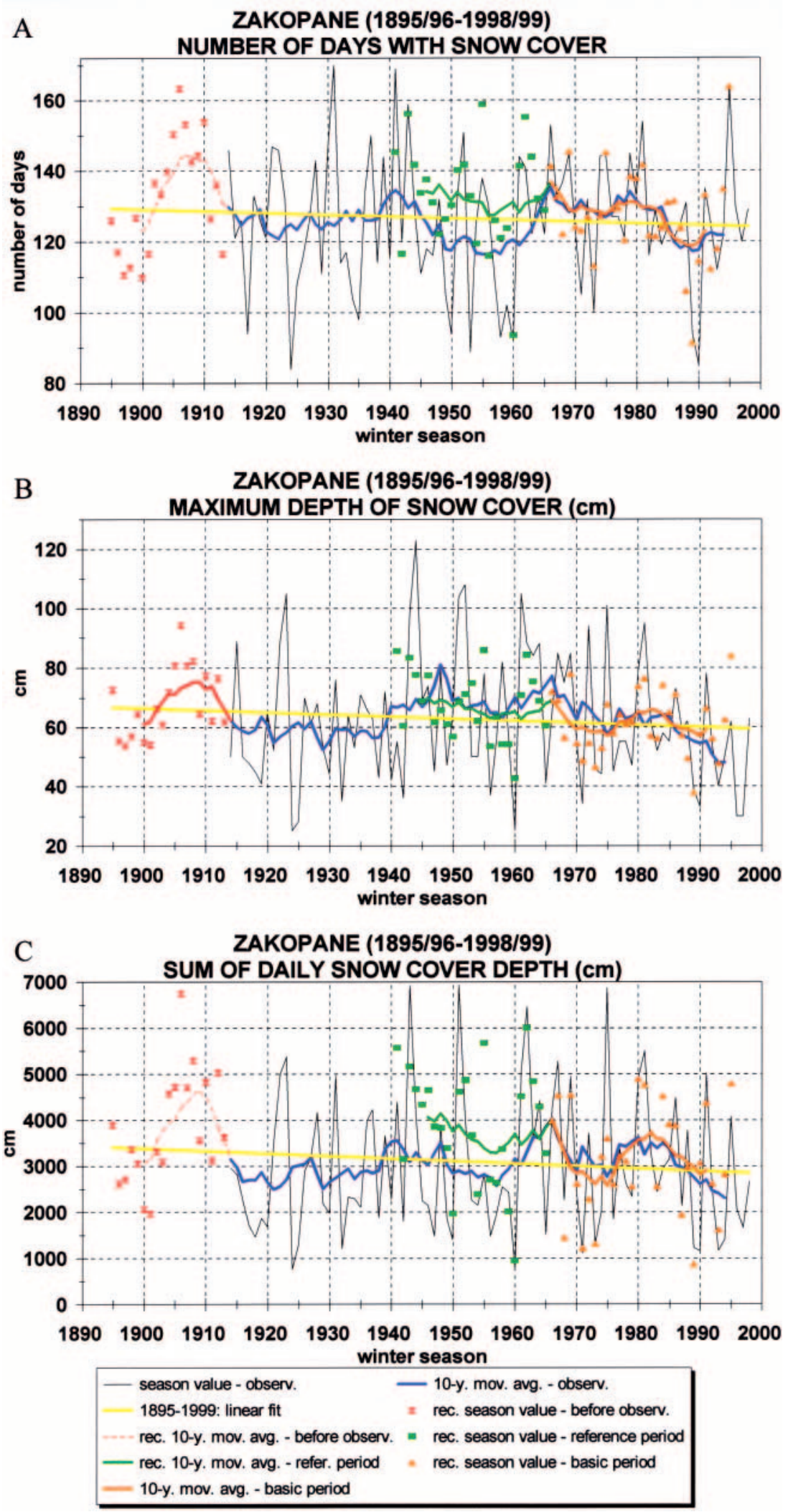

Fig. 6. Zakopane: observed and reconstructed snow cover characteristics (1895/96-1998/99); observ.: observed; rec.: reconstructed; refer.: reference; 1900 means the winter season of 1900/01 etc. cally significant $(\mathrm{p}<0.05)$ decreasing trend of snow cover duration at both stations $(-13 \mathrm{~d} / 10 \mathrm{yr}$ in Cracow, $-8 \mathrm{~d}$ / $10 \mathrm{yr}$ in Zakopane) in the period 1961-1990 could be selected for the whole investigated period. In Zakopane the statistically significant decreasing tendency of maximum snow cover depth continued in the 1990s as well ( $-9 \mathrm{~cm} / 10 \mathrm{yr})$.

The mean snow cover duration at Zakopane is twice as long as that at Cracow. The most abundant nival conditions were observed in the 1960s, while the poorest occurred in the 1990s (except for the extremely long snow cover duration in 1995/96: $133 \mathrm{~d}$ in Cracow) and in some cases in the 1950s (Figs 4 \& 5). The shortest snow cover season was 1924/25, when in Cracow snow cover persisted for $10 \mathrm{~d}$ only. The highest snow cover maximum depth was recorded in Cracow in 1962/63 (65 cm), when the relevant parameter in Zakopane was also much more above its normal values and remained above $60 \mathrm{~cm}$ for about 3 mo (Fig. 7). Apart from showing fluctuations in the duration of maximum snow cover depth $\geq 10 \mathrm{~cm}$, Fig. 7 presents clearly 2 features of a distribution of snow cover depth in a winter season: (1) the maximum value occurs in January-February in Cracow and moves to February-March in Zakopane, (2) the autumn increase in snow cover in Zakopane is much slower than the spring decrease. The variation coefficient of the snow cover duration is over twice as large in Cracow $(37 \%)$ as that in Zakopane $(15 \%)$. At both stations the sum of snow cover depth shows the highest relative variability (50\% in Zakopane, $91 \%$ in Cracow).

\section{DISCUSSION AND CONCLUSION}

The snow cover reconstruction at the turn of the 20th century based on climatic data appears to be more successful for the station located at a lower altitude (Cracow). In this case the results obtained can be consid- 
Table 4. Selected characteristics of snow cover in Cracow and Zakopane

\begin{tabular}{|c|c|c|c|c|c|c|c|c|c|c|c|}
\hline Stn & Average & & $\begin{array}{l}\text { ghest } \\
\text { in season }\end{array}$ & & $\begin{array}{l}\text { Lowest } \\
\qquad \text { in season(s) }\end{array}$ & $\mathrm{SD}$ & $\begin{array}{c}\text { Variation } \\
\text { coefficient } \\
(\%)\end{array}$ & $\begin{array}{l}\text { Change } \\
\text { /100 yr }\end{array}$ & $\begin{array}{l}\text { Change } \\
\text { index } \\
(\% / 100 \text { yr })\end{array}$ & $\begin{array}{l}\text { Analysed } \\
\text { period }\end{array}$ & $\begin{array}{l}\text { Length } \\
\text { of series } \\
\text { (seasons) }\end{array}$ \\
\hline \multicolumn{12}{|c|}{ Number of days with snow cover $\geq 1 \mathrm{~cm}$} \\
\hline Cracow & 60 & 133 & 1995/96 & 10 & $1924 / 25$ & 22 & 36.7 & 3.5 & 5.9 & 1895/96-1998/99 & 104 \\
\hline Zakopane & 126 & 170 & $1931 / 32$ & 84 & $1924 / 25$ & 19 & 15.0 & 0.2 & 0.2 & $1914 / 15-1998 / 99$ & 85 \\
\hline \multicolumn{12}{|c|}{ Maximum depth of snow cover $(\mathrm{cm})$} \\
\hline Cracow & 21 & 65 & 1962/63 & 5 & $1924 / 25,1988 / 89$ & 10 & 49.1 & 2.1 & 10.0 & 1895/96-1998/99 & 104 \\
\hline Zakopane & 63 & 123 & $1944 / 45$ & 25 & $1924 / 25,1960 / 61$ & 20 & 31.9 & -7.0 & -11.1 & $1895 / 96-1998 / 99$ & 104 \\
\hline \multicolumn{12}{|c|}{ Sum of daily snow cover depth $(\mathrm{cm})$} \\
\hline Cracow & 599 & 3336 & $1962 / 63$ & 19 & $1924 / 25$ & 544 & 90.9 & 40.1 & 6.7 & $1895 / 96-1998 / 99$ & 104 \\
\hline Zakopane & e 2977 & 6939 & $1951 / 52$ & 761 & $1924 / 25$ & 1489 & 50.0 & 206.7 & 6.9 & $1914 / 15-1998 / 99$ & 85 \\
\hline
\end{tabular}

ered to be reliable, but obviously with some errors. The quality of results seems to be in some cases comparable with those of Brown \& Goodison (1996). However the results obtained for the number of snow cover days and sum of daily snow cover depth in Zakopane appear to be overestimated, as demonstrated for the reference period. Such results could affect the analysis of long-term snow cover variability. Thus, they have been excluded from further calculations. The multiple regression appeared to be more useful for the reconstruction of snow cover in lowlands, where the snow is not persistent and depends strongly on temperature and precipitation changes during the winter season; this is especially true for temperatures $>0^{\circ} \mathrm{C}$, often leading to the disappearance of the relatively thin snow cover. In the mountainous areas, where the temperature during the winter season is usually below $0^{\circ} \mathrm{C}$ and the ratio of snowfall to the whole winter precipitation amount is much bigger than in the lowlands, the snow cover conditions are not so 'sensitive' to changes of the other climatic elements. This was showed initially by the description of correlation coefficients in

Table 1a. Future research will include an attempt to improve the snow cover reconstruction results by: (1) using multiple regression with the same climatic elements and indices for the reconstruction of nival conditions in the first month of the winter season, then using the obtained results for reconstructing snow in the next month as one of the components of a regression equation and so on; and (2) adopting and using Brown \& Goodison's method for the reconstruction of daily snow cover data.

An analysis of long-term snow cover variability in both Cracow and Zakopane has shown no statistically significant trends for characteristics under investigation for the period 1895/96-1998/99 (1914/15-1998/99). The result differs from those for different areas of the Northern Hemisphere of some of the authors cited in Section 1 (including the prior papers of this study's author carried out over a shorter period), who stressed the decrease in contemporary snow cover time-series. However most of these

Fig. 7. Fluctuations in duration of monthly maximum snow depth $\geq 10 \mathrm{~cm}$ in Cracow and Zakopane (observed data). 1945 means the winter season of 1945/46 
studies are based on a period of 20 to $30 \mathrm{yr}$. At the same time most research based on a long period of time ( 60 to $100 \mathrm{yr}$ ) indicates no significant changes of snow cover.

The global warming found in the 20th century (IPCC 1996) and the increasing tendency of air temperature in Europe in particular in winter (January; Schönwiese \& Rapp 1997) as well as the 'local' trends of the same features (Trepiñska \& Kowanetz 1997, Wibig 2000; e.g. the increase of mean air temperature in Cracow of $1.7^{\circ} \mathrm{C} / 100 \mathrm{yr}$ in January) seem to have no clear reflection in snow cover conditions in southern Poland in the 20th century. However, the quite strong decreasing tendency of snow cover characteristics observed within the period 1961-1990 could be the expression of both general warming and local changes of temperature conditions. The latter is in special reference to the station in Cracow, where the urban heat island effect due to the development of the city became more and more intensive in this period (Trepiñska \& Kowanetz 1997) and the relative decrease of snow cover duration $(-21 \% / 10$ yr) was extremely large (3 times larger than in Zakopane). However, the decreasing tendency is not continued in the 1990s, except for the maximum snow cover depth in Zakopane.

Acknowledgements. I am very grateful to Prof. Hans von Storch for his suggestions and advice on a previous version of this paper. I would like to thank 3 anonymous reviewers for very helpful comments and critiques which improved the manuscript. Special thanks are also due to Keith Byrne for correcting the translation.

\section{LITERATURE CITED}

Alexandersson H (1986) A homogeneity test applied to precipitation data. J Climatol 6:661-675

Beniston M, Rebetz M, Giorgi F, Marinucci MR (1994) An analysis of regional climate change in Switzerland. Theor Appl Climatol 49:135-159

Brown RD Goodison BE (1996) Interannual variability in reconstructed Canadian snow cover, 1915-1992. J Clim 9:1299-1318

CRU (2000) North Atlantic Oscillation (NAO). Climatic Research Unit, Univ. East England, Norwich; available at http://www.cru.uea.ac.uk

Falarz M (1998) Long-term variability of snow cover in Cracow and suburban areas. Acta Univ Lodziensis, Folia Geogr Phys 3:473-481 (in Polish, English summary)

Falarz M, Faško P, Lapin M (1998) Long-term variability of the snow cover in the Western Carpathians. In: 2nd European Conference on Applied Climatology, ECAC 98, 19-23 October 1998, Vienna, Central Institute for Meteorology and Geodynamics, Vienna, p 19:19 (full text on ECAC CD-ROM, Session 1, p 6)

Groisman PY, Karl TR, Knight RW, Stenchikov GL (1994) Changes of snow cover, temperature and the radiative heat balance over the Northern Hemisphere. J Clim 7:1633-1656

Gutzler DS, Rosen RD (1992) Interannual variability of winter time snow cover across the Northern Hemisphere. J Clim 5:1441-1447

Hughes MG, Robinson DA (1996) Historical snow cover variability in the Great Plains region of the USA: 1910 through to 1993. Int J Climatol 16:1005-1018

IPCC (Intergovernmental Panel on Climatic Change) (1996) Climate change 1995: the science of climate change. The Second IPCC Scientific Assessment. Cambridge University Press, Cambridge

Jaagus J (1997) The impact of climate change on the snow cover pattern in Estonia. Clim Change 36:65-77

Karl TR, Groisman PY, Knight RW, Heim RR (1993) Recent variations of snow cover and snowfall in North America and their relation to precipitation and temperature variations. J Clim 6:1327-1344

Niedźwiedź T (1988) Calendar of circulation types for the upper Vistula basin (1951-1985). Zeszyty Naukowe of the Jagiellonien University Prace Geograficzne 71:37-86 (in Polish, English summary)

Niedźwiedź T (1992) Calendar of circulation types for the upper Vistula basin (1986-1990). Zeszyty Naukowe of the Jagiellonien University Prace Geograficzne 90:69-76 (in Polish, English summary)

Niedźwiedź T (1993) Changes of atmospheric circulation (using the $\mathrm{P}, \mathrm{S}, \mathrm{C}, \mathrm{M}$ indices) in the winter season and their influence on air temperature in Cracow. In: Early meteorological instrumental records in Europe-methods and results. Zesz Nauk UJ Pr Geogr 95:107-113

Niedźwiedź T (1998) Variability of atmospheric circulation indices above the Western Carpathians. In: 2nd European Conference on Applied Climatology, ECAC 98, 19-23 October 1998, Vienna, Central Institute for Meteorology and Geodynamics, Vienna, p 19:58 (full text on ECAC CDROM, Session 1, p 6)

Šamaj F, Brázdil R, Dobrovolny P, Faško P, Koštalová J, Valovič Š (1991) Variability of characteristics of snow conditions in Carpathian part of ČSFR within the period from 1920/21-1984/85. Zbornik Prác SHMU Bratislava 34:175 (in Slovak, English summary)

Schönwiese ChD, Rapp J (1997) Climate trend atlas of Europe based on observations 1891-1990. Kluwer Academic Publishers, Dordrecht

Stepanek P (2000) AnalKlim, Software for time series analysis, ver. 3.87. Masaryk Universtiy, Brno. Available at: www.sci.muni.cz/ pest

Trepiñska J, Kowanetz L (1997) Many years' course of mean monthly values of air temperature in Cracow, 1792-1995. In: Trepiñska J (ed) Climate fluctuations in Cracow (1792-1995). Institute of Geography, Jagiellonien University, Cracow, p 99-130 (in Polish, English summary)

Twardosz R (1999) Pluvial conditions in Cracow in the period 1792-1998. Czas Geogr 70:221-234 (in Polish, English summary)

Wibig J (2000) Temporal variability of the frequency of extreme temperature occurrence in Poland on the example of Zakopane and Łódź. In: Obrẹbska-Starkel B (ed) Images of weather and climate. Prace Geograficzne of the Institute of Geography, Jagiellonien University, 108, Cracow, p 215-222

Ye H, Cho HR, Gustafson PE (1998) The changes in Russian winter snow accumulation during 1936-1983 and its spatial patterns. J Clim 11:856-863

Submitted: November 12, 2000; Accepted: May 11, 2001

Proofs received from author(s): October 24, 2001 